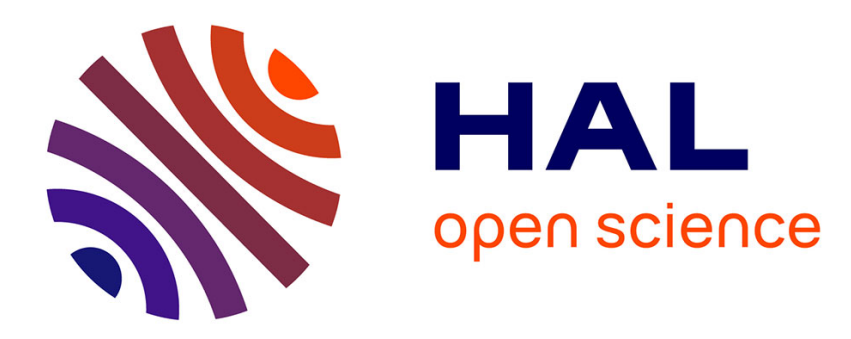

\title{
Pietism and the politics of catechisms
}

Henrik Horstbøll

\section{To cite this version:}

Henrik Horstbøll. Pietism and the politics of catechisms: The case of Denmark and Norway in the eighteenth and nineteenth centuries. Scandinavian Journal of History, 2004, 29 (2), p. 143-160. 10.1080/0346875041000622 . hprints-00254947

\section{HAL Id: hprints-00254947 \\ https://hal-hprints.archives-ouvertes.fr/hprints-00254947}

Submitted on 13 Feb 2008

HAL is a multi-disciplinary open access archive for the deposit and dissemination of scientific research documents, whether they are published or not. The documents may come from teaching and research institutions in France or abroad, or from public or private research centers.
L'archive ouverte pluridisciplinaire HAL, est destinée au dépôt et à la diffusion de documents scientifiques de niveau recherche, publiés ou non, émanant des établissements d'enseignement et de recherche français ou étrangers, des laboratoires publics ou privés. 


\title{
Pietism and the Politics of Catechisms
}

\author{
The Case of Denmark and Norway in the Eighteenth and Nineteenth \\ Centuries*
}

Henrik Horstbøll

In 1885 in Christiania (now Oslo) there appeared a 39-page booklet book entitled "The Shortcomings of Pontoppidan's Exposition and the Principles for a New One". The educator and politician Niels Hertzberg had published the little tract in order to gather support for the renewal of children's religious instruction in schools and churches in Norway. The first sentence posed the problem: "To advocate a new authorized school textbook for Religion or an altered edition of Pontopiddan's text is nothing new, but an old idea within church and school". ${ }^{1}$ Erik Pontoppidan's exposition of Luther's Short Catechism was still a living tradition and a state authorized foundation for instruction in Norway nearly 150 years after the book had left the printing house in Copenhagen, in 1737, with the cryptic title "Truth to God-fearingness".?

Pontoppidan's exposition of the church-catechism was the first general and authorized manual for teaching Christianity in Denmark and Norway, and abridged editions or extracts of Pontopiddan's exposition had for decades replaced the original text on the market. Nevertheless, the manual's main content and key concepts had remained intact.

After the Eidswoll Constitution 1814, it had been decided by supreme resolution in 1818 that Pontoppidan's exposition or Saxtorph's extract of it were the authorized texts in Norway's public schools and to be used for instruction of pupils until a "new manual or new manuals in Religion might be introduced". 3

Erik Pontoppidan's manual was thus Norwegian tradition in the 1800 s, while the situation was completely different in Denmark. Here Pontoppidan's exposition became a symbol of opposition to state power and to the state Church in the first half of the 19th century. In 1794, Pontoppidan's text had officially been replaced by

Henrik Horstbøll, born 1952, D.Phil., research librarian at The Royal Library in Copenhagen. He has published Menigmands medie. Det folkelige bogtryk i Danmark 1500-1840. En kulturhistorisk undersøgelse. 1999, with an English summary: The Culture of Popular Print in Early Modern Denmark 1500-1840.

Address: Det Kongelige Bibliotek, PO Box 2149,DK 1016 Copenhagen K, Denmark.E-mail: hh@kb.dk

* The article is a revised translation of "Lesning til salighed, oplysning og velfard. Om Pontoppidan, pietisme og lærebøger i Danmark og Norge i 1700-og 1800-tallet", Fortid og Nutid, vol. 2: (2003), pp. $83-108$.

${ }_{2}^{1}$ N. Hertzberg, Manglerne ved Pontoppidans Forklaring og Principerne for en ny (Christiania 1885), p. 2.

${ }^{2}$ Erik Pontoppidan, Sandhed til Gudfrygtighed, udi en eenfoldig Forklaring over sal. D.Morten Luthers liden Catechismo (København 1737).

3 Hertzberg, op.cit., p.2. 
a new one authored by Bishop Balle, and in Denmark the authorities retained use of Balle's manual. The authority of the local pastor rose and fell with the ability to keep the former manual out of the classroom. Whereas Pontoppidans book in Norway during the 1830 s contained everything necessary to know about salvation, the struggles in Denmark to obtain permission to use Pontoppidan's text by free choice continued into the 1830s and 1840s in various congregations from Jutland to Bornholm. Pontoppidan's text had been a gathering point for anti-authoritarian revivalist movements that undermined the absolutist state Church.

Few books have had so much power over minds in Denmark and Norway, and few books have aroused so much debate and conflict over such a long period of time as Erik Pontoppidan's exposition of the church-catechism. This is in itself sufficient ground to investigate what it was that preoccupied these minds. Moreover, Pontoppidan's manual had roots in pietist discourse. From the end of the 17 th century and in the beginning of the 18 th, pietist ideas played a key role in church and state policies across national boundaries, stretching from Württemberg over Prussia to Scandinavia. Hence, the history of Pontoppidan's text also has comparative interest for the question of relations between pietism and political culture. ${ }^{4}$

In the following I will discuss some key concepts within Pontoppidan in relation to the manual's historical context: the Second Reformation. What kind of view of man was imprinted on the public in the period, which began in 1730s? I investigate the diffusion of the text and the context of its utilization. What kinds of attitudes about the individual, about society and the authorities were placed at the disposal of the citizens' interpretation of their environment? Finally, I focus on the conflicts in connection with the use of Pontoppidan's manual and the conflicts, which arose when the authorities tried to replace it in Norway and Denmark.

The reason for choosing Pontoppidan's manual and genre is simple: the catechism and its exposition was the portal to the written word. From the Reformation to the first decades of the 19th century, Luther's Short Catechism, together with prayers, psalms and the exposition of the catechism, were the entry into the world of the book, supplemented only by the signs and activities of the almanac and the calendar. For those who overcame the barriers of literacy, the spectrum of possible reading was extended. The foundation, however, was religious reading. However, before we embark on the analysis of Pontoppidan's text, it is necessary to describe the context in which his new religious textbook arose.

\section{"The Second Reformation", 1736-1739}

One of the first official historical commemorations in Denmark and Norway was

\footnotetext{
${ }^{4}$ Mary Fulbrook posed questions concerning the relations between Protestant discourse and economic development, as discussed by Max Weber, in a modern political context in her book, Piety and Politics. Religion and the Rise of Absolutism in England, Württemberg and Prussia (Cambridge 1983). The discussion was continued: Richard Gawthrop, Pietism and the Making of Eighteenth-Century Prussia (Cambridge 1993) and Knud Haakonsen (ed.), Enlightenment and Religion. Rational Dissent in eighteenth-century Britain. Cambridge 1996. A review of the discussion and recent research is presented by James van Horn Melton, "Pietism, Politics and the Public Sphere in Germany", Religion and Politics in Enlightenment Europe, edited by James E. Bradley \& Dale K. van Kley (Notre Dame, Indiana 2001), pp. 294-333.
} 
the Bicentenary of the Reformation. The commemoration of the completion of the Reformation took place in the churches on 30th October $1736 .{ }^{5}$ The Reformation was not only a historical tradition, and the Bicentenary was not only the commemoration of an old victory. It was also an occasion to pursue current ecclesiastical policy. The Jubilee year of 1736 had commenced on 13th January with a decree on the confirmation of youth. ${ }^{6}$

An additional benefit of the youth's confirmation was that "the entire congregation could thereby be reminded of its duty and obtain an admirable occasion to good and fruitful construction of its Christianity". ${ }^{7}$ But how? The brief, almost compressed questions and answers in Luther's Short Catechism could be laid out and learned in many ways, and there were many expositions circulating on the book market. In principle, the University of Copenhagen subjected all the books to theological censorship. However, sorting out the clearly distorted teachings was quite different from establishing an authoritative set of precepts in line with the modern religious tendencies of a moderate pietistic character. This was the concern of the King and of the main part of the Government. In the Jubilee year of 1736, Christian VI had his court pastor, Erik Pontoppidan, begin drafting the obligatory confirmation manual - the new exposition of the church-catechism.

Erik Pontoppidan, along with Andreas Hojer, was a key personality in the Reformation campaign, which culminated in the years around the Jubilee activities. After several years as parish pastor on the island of Als, Pontoppidan had become pastor to the King at Frederiksborg castle. That same year he published his own history of the Reformation. Pontoppidan's pietism suited the King, and the following year saw Pontoppidan become pastor to the court. In the year of the Bicentenary, he published in Latin his strange little pamphlet with the title "Broom for Sweeping out the Old Remnants", an instructive tract which used cultural historical documentation to explain the timeliness of a renewed Reformation against extant active remnants of both paganism as well as Catholicism, known as Papism. ${ }^{8}$

In practice, Erik Pontoppidan elaborated "the broom" which was to do the "sweeping": the new exposition of the church-catechism. Pontoppidan was to replace the local variations of catechism instruction with an authorized uniform framework.

Pontoppidan's model was the German pietist Ph. J. Spener's "Einfältige Erklärung der christlichen Lehre"(1677), which appeared in Danish translation in $1728 .^{9}$

${ }^{5}$ The Reformation was commemorated in 1717 from 31st October to 7 th November in Denmark and Norway too, Bibliotheca Danica, vol. 1 (København 1877), pp. 151-154. The Bicentenary was repeated as a local event in 1736, Bibliotheca Danica, vol. 2 (København 1886), p. 906.

${ }_{6}^{6}$ Edvard Holm, Danmarks-Norges Historie (1720-1814) vol. 2 (København 1893-94), p.651.

${ }^{7}$ Decree from 13th January 1736, J.H.Schou \& Kolderup Rosenvinge Chronologisk Register over de Kongelige Forordninger og Aabne Breve... 1670-1849, (København 1795-1850).

${ }^{8}$ Erik Pontoppidan, Fejekost til at udfeje den gamle surdegg eller de $i$ de danske lande tiloverblerme og her for dagen bragte leoninger af saavel hedenskab som papisme, edited by Jørgen Olrik, (København 1923).

${ }^{9}$ Phil. Jac. Spener, Den christlige Lardoms eenfoldige Udleggelse efter D. M. Lutheri liden Catechismi Orden, (København 1728). The book was reedited in 1730 and 1740, Bibliotheca Danica, vol. 1 (København 1877), p. 266. Martin Brecht: "Philip Jacob Spener, sein Programm und dessen Auswirkungen", Martin Brecht (red.), Geschichte des Pietismus, bd. 1, 1993, p. 440. 
In July 1737, the printing house at the Vajsenhouse in Copenhagen obtained the rights to publish the new textbook, in return for annually distributing 1500 copies among the poor. ${ }^{10}$ A large-scale book production was begun, and the manual became one of the 18th century's largest book projects. In August 1738, the project had reached the point where the King could decree that all new pupils in Denmark and Norway should use the book. ${ }^{11}$

But how could the central state power ensure that its intentions would be realized, that the true Christianity took root, that it was actually preached in church, taught in the schools or by the vicar, and that these teachings were realized in the life of the congregation?

In connection with the commemoration of the Bicentenary in 1736 a decree was issued by Christian VI ordering the professors at the University and the bishops to report once a year about the intellectual and social behaviour of the young candidates and the new pastors. The unsuitable candidates could then be sorted out and the congregations could be shielded from distorted teachings and scandalous teachers. ${ }^{12}$ The central administration asked 32 questions concerning the life style and the abilities of the future pastors to secure a uniform examination. The decree was a prediction of a new development in the policies of the ecclesiastical affairs. As a change the head of the chancellery would get the last word in matters of church inspection in the future, and the bishops lost some of their authority to the civil administration. It must have been the opinion of the King that the church could not manage the task of cleansing and renewal alone. The aim of the inspection of the church was not just to get rid of false prophets and scandalous teachers; a clash between the old orthodox tradition and the new pietist ideas was embedded in the inspection. Like the King himself, the head of the chancellery, J. L. Holstein was deeply influenced by the revivalist pietist movement from Halle. ${ }^{13}$

The decree did not become an empty text. A new Department of the Inspection of the Church was established within a year, and it enjoyed the same status as the other departments in the administration. The Department of the Church, as it was normally named, gained power over the ecclesiastical affairs from three authorities: It replaced the bishops, and especially the bishop of Seeland, Kristen Worm as the chief advisor to the King in religious matters. The Department was established without the consent of the bishop Kristen Worm. His successor, Peder Hersleb became an ordinary member of the Department whose head was J. L. Holstein. It was both practical and opportune that Holstein was the president of the chancellery too. The chancellery was the second institution that transferred authority to the Department of the Church and Holstein was the guarantee of continuity in the administration. The third institution that delegated authority was the University:

${ }^{10}$ Rescript, 19th July 1737, L. Fogtman \& Algreen-Ussing, Kongelige Rescripter, Resolutioner og Collegialbreve 1660-1848, (København 1786-1854).

${ }_{11}$ Rescript, 22nd August 1738, Fogtman, op.cit.

12 Decree, 2nd November 1736, J. H.Schou: op.cit.

13 About the general reception of pietism and the historiography of pietism in Denmark: Tyge Krogh: "Rationalismens syndebuk. Christian 6. og pietismen i dansk historieskrivning", Ning de ConinckSmith, Mogens Rüdiger og Morten Thing (red.): Historiens Kultur. Fortalling, kritik, metode, 1997, pp. 61-79. About the introduction of pietism in Copenhagen in the beginning of the 1730s : Thomas Bredsdorff, Den brogede Oplysning, København 2003, p. 31-78. 
The censorship of books had been the duty of the professors since the Reformation, but the Department of the Inspection of the Church could now overrule the university in matters of censorship. Furthermore the Department should propagate the diffusion of religious reading among the population. "The Church Inspection should be the instrument of "the Second Reformation".

The key person behind the development of the Department of Church Inspection was Andreas Hojer, the most important judicial expert in the Government and the man who actually wrote the decrees. By his death in 1739 the most dynamic period of the inspection of the church came to an end. Just before his death a school reform was passed. According to the decree everybody would have to attend school from the age of five or six till the final examination: the confirmation. ${ }^{15}$

The general elementary school should have been the climax of "the Second Reformation", but the decree promised more than could be realized. With the lack of a school tax and without a centralized education of school-teachers much remained unchanged. The general school system was only realized more than half a century later, but the reforms of the 1730s had other far-reaching effects and the most important were the effects of the compulsory confirmation of youth.

To conclude: The reforms following the Bicentenary of the Reformation took place at three levels: At the level of the government the central administration of ecclesiastical affairs was reorganized in the Department of Church Inspection. At the level of the church the bishop supervised the relation between the pastor and the congregation. And finally, every individual had to cope with obligatory religious education and the confirmation.

The confirmation was not welcome news to everybody, but if somebody tried to evade it the pastor had to act - if not the bishop or the Church Inspection should react. The use of the decreed exposition of the church-catechism was a central part of the new conditions. Erik Pontoppidan's book became the cutting edge of the Second Reformation. It was to be the instrument for creating the disciplined, Christian citizen through uniform instruction and readings. What was the nature of this truth to God-fearingness?

\section{Enlightenment and pietism}

Pontoppidan began his work from a historical perspective: "We live in an era when secular wisdom and all types of knowledge founded upon this are on the path toward a higher degree than our ancestors could possibly have imagined". ${ }^{16}$ No one in the secular sciences at that time would be content with half-truths of the past, he wrote in the introduction to the first edition. A similar development concerning the insight in "Truths of Religion" was both desirable and opportune.

We thus witness a 1737 version of optimism. This optimism is founded upon

${ }^{14}$ Decree 1st October 1737, J. H.Schou: op.cit.

15 Joakim Larsen: Bidrag til den danske folkeundervisnings og folkeskoles Historie 1536-1784, 1916, s. 236-265.

${ }^{16}$ Pontoppidan 1737, op.cit., Preface. 
pietism, and upon words such as "light", "enlightenment", "reason" and "truth", all key concepts in the exposition of the catechism.

"Light" was a central metaphor and enlightenment a key concept. In the 18th century, "enlightenment" had both a worldly and a spiritual dimension. Only in the final decades of the century did the enlightenment concept become explicitly secularised, as we find it in Kant. ${ }^{17}$ For Pontoppidan, enlightenment thus has a dual meaning: light is "the advantage of our era over that of our forefathers". Darkness and twilight can now be left behind. Besides this secular and intellectual dimension of enlightenment, however, the light of truth and the true enlightenment also have a spiritual significance for Pontoppidan.

On the question of what "The Word" does to those who convert, allow the gospel to come into their heart, the answer is unequivocal: enlightenment. It means living knowledge and strong conviction about the divine truths. ${ }^{18}$ But continues Erik Pontoppidan: Tell me the real difference between human teachings and divine enlightenment!

In the following key answer, which has certainly caused many pupils to break out into a sweat during their examination, he distinguishes between teachings, which by reason and diligence are learned by The Word, and enlightenment, which is made active by The Word. Teachings are located only in the brain and are "a simple historical knowledge", while enlightenment occupies the heart. In the distinction between the light in the brain and the enlightenment of the heart, we find the 18th century's dual concept of enlightenment sharply formulated: Light has one dimension conditioned by reason and another inconceivable, emotional dimension. There is a decisive difference between the two dimensions, but not necessarily any contradiction or conflict. On the contrary, religious enlightenment is the key prerequisite for the rebirth of the individual. Here we are at the very core of Pontoppidan's manual. The enlightenment of the heart entails the rebirth of a new person: "in reason a new light, in will a new longing, desire and strength". ${ }^{19}$

The Word was the key concept throughout several themes of the exposition, and at the beginning of the book Pontoppidan defined the meaning of the concept: " 1 . Dear Child, would you like to be happy on Earth and redeemed in Heaven? Yes, if only I could be so." The initial question of "Truth to God-fearingness" was followed by a statement of Pontoppidan that the road to redemption was shown by the Word of God in the Holy Writ. But writing belongs to mankind and the question appears: Who wrote the Bible? Although the writers of the Gospel wrote by the inspiration of God, they were writing, human beings. How one could separate historical truth from heavenly truth was a central problem from the beginning of the book.

The first doubt to be managed by the Christian reader was "whether the Holy Writ - as we have it - is the true word of God?" Pontoppidan built his answer on the effects achieved by the Word "without Force and human Power", and on the

\footnotetext{
17 "Aufklärung ist der Ausgang des Menschen aus seiner selbstverschuldeten Unmündigkeit. Unmündigkeit ist das Unvermögen, sich seines Verstandes ohne Leitung eines anderen zu bedienen." Immanuel Kant: Beantwortung der Frage: Was ist Aufklärung?, Berlinische Monatsschrift Dezember-Heft 1784, s. 481. Translated to Danish: Hvad or Oplysning? En Afhandling, 1797.

${ }_{18}$ Pontoppidan 1737, op.cit., \$482-483.

${ }^{19}$ Pontoppidan 1737, op.cit., \$487-488.
} 
effects achieved in the heart of the individual. Not all words in writing should be trusted: Aside from the true Word one could read other texts, like "old Opinion, Proverbs and Custom", all kind of stories without any foundation. New knowledge should replace the old historical traditions, but the tradition of the Word should stand.

Having come so far, Pontoppidan could pose the main question: "How does one act correctly with God's Word?" The answer was simple: when one first beseeches God about his spirit's enlightenment, and then reads with piety and serious afterthought, one can then act correctly with the Word. One must read, but one must read in order to satisfy the hunger of the soul, not the curiosity of the flesh. One must not distort the words according to one's own belief, but must search "in an impartial way therein for The Truth which is to God-fearingness and try one's own heart after this". ${ }^{20}$ By whom should the Holy Scriptures be read? By everyone.

The Holy Writ was but the medium, which transmitted The Word to the reader, just as reading with eye and brain helped transmit The Word to the heart, where true enlightenment was made active. The result, however, was dependent upon the process: there was no true enlightenment without learning. The teachings of the brain were to a certain degree a prerequisite for the enlightenment of the heart and thereby for the formation of the Christian individual. Literacy was the minimum requirement. It was a decisive step on the path toward salvation.

Pontoppidan claimed to represent a new time and a new beginning, but what was actually new in the form and content of his exposition?

\section{The List of Duties}

The Gentenary of the Reformation in Denmark in 1636 had occasioned the publication of an exposition of the church-catechism too. The bishop Hans Poulsen Resen was the author, and he made it clear from the beginning that it was the duty of the pastor to teach and to put the members of his congregation through their catechism. That was a decision from the time of the Reformation and in 1629 a decree had enjoined the duty on the youth to learn the church-catechism before they attended the Holy Communion. Hans Poulsen Resen also considered his book to be a new beginning. ${ }^{21}$

Resen did not explain the contents of Luther's Church-Catechism and the manual was strictly speaking not an exposition of the catechism at all. It was an exposition of the "List of Duties" that traditionally brought the text of the catechism to an end. Resen's book offered a manual about how to behave well in a Christian manner.

The List of Duties was essential to the religious textbooks of the seventeenth and early eighteenth century and Resen had many rivals on the book market. ${ }^{22}$ Pastors wrote their own expositions and they were supplemented by German texts in translation.

\footnotetext{
${ }^{20}$ Pontoppidan 1737, op.cit., $\$ 9$.

21 [Hans Poulsen Resen]: Instructio executionis catechetica, secundum Lutherum. Huorledis Catechismi Øfuelse bør at drifuis, efter Luthers rette Meening, Indledning, upag., 1636.

22 Charlotte Appel: Lesning og bogmarked i 1600-tallets Danmark, 2001, s. 129-159.
} 
Ph. J. Spener's "Exposition of the Christian teachings of Matin Luther" was printed in Copenhagen in 1728. Spener's book was the model, in both form and content, for Pontoppidan's catechism, but Spener's text was long and the Danish translation convoluted. ${ }^{23}$ While Pontoppidan chose to retain Spener's construction of the exposition in the form of questions and answers, he rewrote the text and reformulated the key concepts. At the same time he decided, with a certain symbolic value, to abolish the list of household duties, which was still an independent text in Spener's book. The world of the "List of Duties" now belonged to the past.

\section{Self-love, love of thy neighbour and citizenship}

With the elimination of the list of duties, an independent review of the estate society's duties of obedience was kept out of the decreed manual. What remained was the recapitulation of the obligations according to the Ten Commandments, where duties to the state, to the household and to the family became part of the exposition of the "second table" of the commandments.

The "first table" of the Ten Commandments consists of the first three commandments; taken together they deal with "love to God". To the question, "What is the essence of the second table?" Pontoppidan answered: "Love to ourselves and to our fellow man". ${ }^{4}$ It is in the second table that we must seek Pontoppidan's social teachings and they, quite surprisingly, take their point of departure in love of ourselves - in the individual's own self-love.

In reality, it is quite consistent to begin with the precondition of love of one's neighbour (cf. Matthew, Ch. 22, v. 39): "Thou shalt love thy neighbour as thy self", which brings the catechism's first question, "Is it indeed right to love oneself?"

"Yes", answers Pontoppidan, as long as love of self is orderly and innocent. But what is the nature of an orderly and innocent self-love? "It is a desire implanted in Man by God to make possible his true welfare and salvation". ${ }^{25}$ This new concept of welfare becomes a central feature of Pontoppidan's social vocabulary.

The key to the understanding of loving thy neighbour and the obligations of the citizen in Pontoppidan is love of self. The positive formulation - that one must treat one's fellow citizens or neighbours as one would wish to be treated - is turned on its head by Pontoppidan: "When I insert myself in the place of my neighbour, and ponder whether I will fight wildly with him, be cursed, cheated, robbed, criticized behind my back, and that in my owen self-love say, ' $N_{0}$ ', it is for me a rule of love toward my neighbour". ${ }^{26}$ In this way, Pontoppidan establishes a social individual. In this minimal version the utopian demand to love thy neighbour becomes a social opportunity: It opens the perspective of linking together earthly welfare with heavenly salvation.

By the choice of self-love as a key concept in the preface of the exposition of the second table Pontoppidan placed himself in a main stream of the moral philosophy

\footnotetext{
${ }^{23}$ Spener 1728, op.cit.

24 Pontoppidan 1737, op.cit., \$141.

25 Pontoppidan 1737, op.cit., §144.

${ }^{26}$ Pontoppidan 1737, op.cit., \$149.
} 
of the eighteenth century: In $A$ discourse on the Origin of Inequality (1755) and later in The Social Contract (1762) Jean-Jacques Rousseau investigated the distinction between the positive, social self-love - "amour de sor" - and the negative, accumulating egoism - "amour propre". The love of self led to the concept of compassion - "pitie" - because it was painful for man to witness the suffering of a fellow-being that he could recognize as resembling himself. On the other hand the more egoist "amour propre" led man to his Fall on earth - led to the chains of inequality and to the social state of conflict. Rousseau did not develop his social anthropology and moral philosophy in a theoretical vacuum. He wrote within a discourse and a vocabulary of the 18 th century. ${ }^{27}$ The writings of Pontoppidan in the 1730s must be seen in this wider intellectual framework: He tried to modernize the education and to bring it up to level with the improvements in other fields of knowledge at the time. The result appears as a combination of the secular Enlightenment's view of man as a social being with the sin-conscious demands of pietism for active intervention, action and strength of will. In Pontoppidan's reborn, Christian person, one catches a glimpse of the 18th century's new, self-assured social individual - the individual possessed with a moral sentiment.

\section{The dissemination and application of "Truth to Godfearingness"}

The King decreed that Pontoppidan's catechism exposition be used in all churches and schools and at private instruction in Denmark and Norway. The question, therefore, is not whether it was disseminated, for indeed it was, but, rather, how it became disseminated.

As mentioned, the Vajsenhouse printing house obtained sole rights to publish the book on 19th July 1737. With the publication privileges, the printing house obligated itself to meet the demand for catechism expositions for a fixed price of 10 Danish shillings and to deliver 1500 copies annually for distribution among the poor. From the Vajsenhouse executive negotiations, we read that a normal press run of an edifying instruction manual was 2000 copies. ${ }^{28}$ It was thus almost an entire press run that was to be donated, and this provides some indication of the massive order that the Ecclesiastical central administration had given to the printing house.

The Vajsenhouse certainly had plenty enough to do. In 1743 , in a letter to the Ecclesiastical administration, Erik Pontoppidan mentions in passing that the printer had by that time distributed 70,000 copies, i.e., more than 10,000 a year. $^{29}$ Pontoppidan's book was thus on permanent order at the Vajsenhouse, and remained so for decades. The list of various preserved editions is impressive: from

${ }^{27}$ G. D. H. Cole "Introduction" to The Sacial Contract and Discourses, London 1973 s. XV. Iring Fetscher: Rousseaus politische Philosophie, 1975, s. 65.

28 Holger Frederik Rørdam, "Blade af Waisenhusets ældste Historie", Firkehistoriske Samlinger 4.R. 3: (1893-95), p. 37. Harald Ilsøe, Bogirykkerne i Kobenhaun og deres virksomhed ca. 1600-1810 (København 1992), p. 116.

${ }^{29}$ Holger Frederik Rørdam, "Præsten Niels Tøxen i Verst, Orthodoxiens Ridder i Pietismens Tid", Kirkehistoriske Samlinger 5.R. 1: (1902-1903), p. 460. 
the 1700s, over 40 different editions of Pontoppidan's exposition of the Churchcatechism have been preserved. ${ }^{30}$

In the early years, sales of the book overshadowed the obligation to distribute the free copies to the poor. TheVajsenhouse did not fulfil its distribution obligations, nor were these obligations precisely formulated as to how and when the distribution should take place. A new decree, issued on 11 th May 1742, clarified these matters. Every third year, 4500 copies of the book should be distributed among the parishes of Denmark and Norway. The bishop should distribute the books among the churches in his region and would be charged with ensuring that they were given to those who were most needy and willing to learn. ${ }^{31}$ Even though this amounted to no more than two free books to each parish, the intentions of the Ecclesiastical administration were clear: the book should reach every corner of Norway and Denmark.

But how should the catechism exposition be used? What should the pastor, or the local schoolteacher if one existed, do with the many questions and answers?

Pontoppidan had designed the book with marks in the margin showing what was only to be read but not to be learned by heart. Thus the pensum was reduced by a third. Approximately one hundred pages remained and apparently the government had burdened the youth of Denmark Norway with the duty to learn a complicated text by rote, but that was far from the idea of the authorities.

The open letter which introduced the new catechism exposition as authorized reading contained some important pedagogical considerations. In fact, it appears that it was not intended that the youth should recite the explanation word for word. Rather, the intention was that they should understand the content and be able to recapitulate it in their own simple words. ${ }^{32}$ The change from learning by rote to comprehension was in this way decreed by law in connection with the new exposition of the catechism.

To meet the intentions of the Department and to remedy the shortcomings of the pedagogical instruction in the decree, Pontoppidan wrote a "A short Instruction for School Teachers. How they could learn the Children to read in Books in the right Way". It was published in Bergen in 1748, but the only surviving copy is an anonymous reprint from Copenhagen $1763 .^{33}$

The instruction speaks to the Norwegian teachers and presents a general method: The children should proceed from the reading of letters to the reading of syllables to the final reading of words, and "the practice of reading in book must not be changed to learning by rote in a hurry because it is harmful and it has as a consequence that many children never apprehend the ability to read". 34 "The next step in the process involves Pontoppidan's exposition of the catechism. The

${ }^{30}$ Bibliotheca Danica, vol. 1 op.cit. p. 266-267. Mogens Brøndsted, "Historien om Potoppidans »Forklaring « i Danmark og Norge". Fund og Forskning 12: (1965), p. 52.

31 Rescript, 11 th May 1742, Fogtman, op.cit.

32 Rescript, 22nd August 1738, Fogtman, op.cit.

33 H. Ehrencron-Müller: Forfatterlexikon omfattende Danmark, Norge og Island indtil 1814, pp. 112 + suppl., pp. 1924-1939, bd. 6, p. 329.

${ }^{34}$ Erik Pontoppidan: Kort og eenfoldig Undervïsning for Skoleholdere, om den Maade, paa huilken de best kunde lere Borm at lese $i$ Boger, saa og ved barnagtige Ord begynde at tale med dem om Gud og hans villie til.vor Salighed, 1763 , p. 14. 
conclusive, final chapter of the book with the title "A short Notion of the redeeming Truth" provides the ideal text to the practice of "reading in book", because the letters are bigger than in the rest of the book and the text is short.

What did the children learn from the very first exercise of "reading in book"? The conclusion of the exposition dealt with the repetition of the Scripture point by point: The Creation, Heaven and Hell, Paradise, the Fall, the Redeemer and Redemption, and at last it dealt with the possibility of the individual, personal salvation: The revival from spiritual death and the rebirth of a new person who gets "in reason a new light, in will a new longing, desire and strength, a reborn mind and heart". ${ }^{35}$ At the entrance to the written word the child should at once learn about the rebirth, true enlightenment, will and welfare.

Pontoppidan's instruction for schoolteachers must be seen as a supplement to the exposition and as his attempt to reach a younger population than the youth attending preparation for confirmation. He developed his ideas about the education of children in a separate chapter titled: "Recollection how Difficult it is to speak to Children in an understandable Way according to the Childish Notion". ${ }^{36}$

At the middle of the eighteenth century the child and childhood had the attention of Pontoppidan: From an early age upbringing and education should create a Christian subject, but it was difficult to talk to children, and the attempt to speak in a way that took the notions of the child serious was new too. The bishop understood the necessity of adapting words and concepts to the universe of the child. If that were not done, the child would only have been taught "some barren words to play with and get used to without the least taste and sense in the heart. The dead and senseless Christianity so common among young and old develops from this habit in the childhood". ${ }^{37}$

Without hesitation Pontoppidan wrote a "Childish Talk with Children about Religious Matters" - a prescription about the education of children at the age of four or five years. He tried to speak in a puerile or childish key about matters not childish at all, and he concluded: "Look, my dear child! This is a short and puerile lesson about God and your Redemption. If you would like to know more, go to school and be diligent. Mark the words of the schoolmaster and let him teach you how to read in books, especially the books named the Catechism and the Bible. That is the Word of God". ${ }^{38}$ It appears that reading and the Word is the next necessary step on the road to salvation.

\section{The reception of Pontoppidan's exposition of the Church-catechism}

It was unavoidable that a new instruction manual, which took a position on the theological controversies of the time and broke with the patriarchal list of duties, would arouse opposition and even resistance. In the town of Aarhus, the pastor Fr. Nannestad attacked the book from the pulpit and would have it burned, though he

\footnotetext{
35 Pontoppidan, 1737, §223-224.

36 Pontoppidan, 1763, pp. 16-20.

37 Pontoppidan, 1763, p. 18.

38 Pontoppidan, 1763, pp. 35-36.
} 
ultimately came to use it. ${ }^{39}$ Erik Pontoppidan summarized the book's reception in a letter to the central administration - the Church Collegium - in the following way: "How the audience received it is well known, the common people corrected themselves at each place according to the various tastes of its clerical authorities". 40 It was their vicar's judgement that was decisive for the opinions of the ordinary layman, and among the sceptical vicars there was one who took up the cause of resistance: Niels Tøxen, pastor in the parish Verst and Bekke in the hundred of Andst, outside the east Jutland town of Kolding.

When Bishop H. A. Brorson, at a countrywide church assembly in Ribe in 1742, reminded the pastors of their obligations to utilize the authorized catechism exposition, Tøxen went for his pen and complained about Pontoppidan.

Tøxen argued that the good self-love was the root of all the evil in Pontoppidan's book. Tøxen could find no command for self-love in the Holy Scriptures; he saw it as being Pontoppidan's invention. The background for Tøxen's anger about selflove was the consequences it obtained for the Christian view of man. In Pontoppidan, it was somehow possible for man to keep to God's law. This law, in its strictest version, demanded unconditional love of thy neighbour. It was a monstrosity that mankind, no matter how converted and reborn it might be, was no longer completely powerless before God. When this was added together with Pontoppidan's concept of enlightenment, the perspectives became baffling. ${ }^{41}$ Man was neither completely powerless before God nor completely dependent on his local vicar. Tøxen's resistance ultimately led to his being dismissed as vicar. A new pastor was named, enabling Pontoppidan to be read by the congregation in Verst.

After these "birth pangs", there was official tranquillity regarding the school textbook situation, and the only nod toward the critique was the approval to publish an abridged version of the catechism exposition in 1771 during the Struensee regime. The writings of Peder Saxtorph, the pastor and member of the Hutterite Brethren Society in Copenhagen, were important within the revivalist circles, and it was Saxtorph who edited the "Extracts of Erik Pontoppidan's Exposition, Excerpted for the Use by Simple Folk". ${ }^{42}$ The "Extracts" radically reduced the extent of questions and answers, but from 1785 it appears in an "enlarged and improved edition", where Saxtorph anonymously returns to a more detailed version of Pontoppidan's text, including the distinction between proper and improper self-love. In Copenhagen "The Extracts" went out of print after 1798 , but in Norway the book obtained a long life on the book market, comprising the basis for the many Norwegian Pontoppidan extracts in the 1800s.

\section{The replacement of Pontoppidan's "Exposition"}

During the culmination of the rationalist tendencies in the first years following the French Revolution, efforts began to create a new manual for religious instruction. The result was Bishop Nicolaj Balle's "Manual of the Evangelical-Ghristian

\footnotetext{
${ }^{39}$ M. Neiiendam, Erik Pontoppidan. Studier og bidrag til pietismens historie, vol. 2 (København 1933), p. 265.

40 Rørdam 1902-1903, op.cit., p. 459.

${ }_{41}$ Rørdam 1902-1903, op.cit., pp. 427-432.

42 [Peder Saxtorph], Udtog af Erik Pontoppidans Forklaring, til de Enfoldiges Nytte uddraget (København 1771).
} 
Religion, Prepared for Use in the Danish Schools". ${ }^{43}$ In 1794, Balle's text was declared universal and compulsory reading. Pontoppidan was replaced - at least officially. The introduction of Balle's manual gave rise to several conflicts - mostly in Norway, but also on the island of Bornholm and in Jutland. ${ }^{44}$ The conflicts raged between the state-ecclesiastical power in Copenhagen and local congregations in the periphery. No longer were these controversies limited to the clerics and within the church's administration. It was now a conflict between the common people and the authorities, between citizens and the state.

The congregations kept their children home from school (and from the book of Bishop Balle), while they met privately to read Pontoppidan's exposition and his edition of Kingo's psalms. The same book which had previously been diffused by way of royal decrees could not be eliminated by law, nor by any sort of verdict in the parishes, where Pontoppidan had contributed to: "in reason a new light, in will a new longing, desire and strength".

The situation became especially tense in the eastern Jutland area around Kolding, Horsens and Vejle. It was not far from this parish that pastor Tøxen had fought against the Bishop and the Church Collegium, having expressed his fear of Pontoppidan's "enthusiasm". At that time, it had been incumbent upon the authorities to press forward with the authorized catechism exposition, with its emphasis on the need to achieve reading for understanding. After a little more than half a century of this kind of literacy the authorities had lost control over the uses of literacy. Even with fines and punishments, it was not possible to prevent the revivalist congregations from using Pontoppidan's textbook. The feud culminated with the "Great Pontoppidan Address", a request from the parish of Øster Snede to the Chancellery in 1835, supported with signatures from the entire country, for the free exercise of religion. ${ }^{45}$

In the congregations Pontoppidan's exposition of the church-catechism symbolized an independence of the ecclesiastical authorities and a right to an individual religious practice. The conflicting politics of catechisms makes it relevant to investigate the character of the book of bishop Balle. Though hated by the antagonists the social teachings of Balle was not radically different from Pontoppidan's exposition. Concerning the duties towards ourselves Balle is quite clear in 1791: "We must love ourselves to care about our Soul and furthermore we must care about the true needs of our body too. We must improve our temporal welfare in accordance with the word and will of God". ${ }^{46}$

The social consequences of self-love are developed by Balle, and he defines what he means by the care for our temporal welfare: "a) By diligence in our work and by wise economy, we must strive to increase our wealth to our own benefit as well as to help others in need. b) In our striving towards wealth we should beware of illegal

${ }^{43}$ [Nic. Eding Balle \& Chr. Bastholm], Larebog i den evangelisk-christelige Religion til Brug $i$ de danske Skoler (København 1791).

44 Brøndsted, op.cit., pp. 53-64.

45 Anders Pontoppidan Thyssen, Vekkelsemes frembrud i Danmark i farste halvdel af det 19. arhundrede. Vol. 4: De ældre jyske Vækkelser, (København 1967), p. 232.

${ }^{46}$ [Nic. Eding Balle \& Chr. Bastholm]: Lærebog i den evangelisk-christelige Religion til Brug i de danske Skoler, 1791, p. 60. 
profit and avarice, and we should not strive towards riches because it often leads to pride and luxury". 47

Now welfare is seen in connection with wealth, and as it was the case by Pontoppidan welfare is a keyword in Balle's discussion of the "Duties" of the authorities: The welfare of the subjects should be an object and aim of the authorities. $^{48}$

The continuity in the social discourse must not erase the serious fact that the two manuals differ widely. In the book of Bishop Balle not a word is found about the divine "enlightenment" of the heart and the rebirth of the individual. Enlightenment consists in learned commentaries to the religious text on geography and other secular matters. Learning was synonymous with enlightenment in the vocabulary of Balle and a change of keywords appeared in this discourse in 1790s. The conceptual change in the social and moral discourse on man and society had taken place in 1737 .

The conflicts surrounding the replacement of Pontoppidan's manual were viewed at that time and afterwards, as a rebellion against the modern ideas of enlightenment from a common people, which held onto their tradition-bound

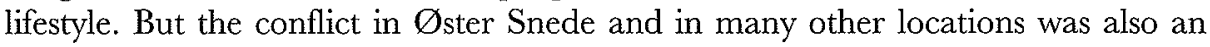
unintended consequence of the intensified diffusion of literacy and of the teachings, which had been the original intention of "the Second Reformation".

The reforms of the 1730s reflect various state interests. There is the interest in educating the population as both Christians and as citizens. In addition, we can identify the state's interest in increased control of society at all levels. In the form Pontoppidan rendered to the instruction, the first interest became an obstacle to the second.

The struggle over Pontoppidan's manual was not only a struggle between modern, enlightened ideas and traditional ones. In its content, it was a case of a conflict between two different versions of the modern breakthrough in catechism teaching in the 18th century. It was a conflict between Pietism and Rationalism, whose social views of man worked for some of the same goals as those which opposed the orthodoxy of the past.

"The Second Reformation" changed the traditional kind of reading symbolized by "The List of Duties". A new kind of reading of prescribed texts was situated outside the household in the religious education preparing for confirmation.

\section{Welfare and economy}

As a vice-chancellor at the University of Copenhagen Erik Pontoppidan edited eight annual volumes of Denmark's and Norway's Economic Magazine from the appearance of the first volume in 1757 to the last in 1764. The magazine pulled together the strands of the debate about the economical improvement of Denmark and Norway. The magazine's function was to publish "private thoughts of various economically-minded Danish and Norwegian patriots... for further scrutiny, and

47 Balle, 1791: op.cit., p. 63.
48 Balle, 1791: op.cit., p. 80.

Scand. F. History 29 (2004) 
general utility and benefit"; and under the heading of economy was collected together whatever was "serviceable for the advancement of the general welfare". Thus, economy embraced that which was useful to ordinary people in terms of the creation of welfare. ${ }^{49}$

In the preface to the volume in 1761 Pontoppidan made a general moral philosophical statement about his view of mankind: Like the planet Earth does not stand, but goes round the Sun, the mind of man can not stop to search for something new. "Although this concealed desire sometimes misguides the human mind through error: By itself, it is a desire implanted in our nature by God almighty. It is not his will that the water should rotten and stink from lull, nor that the minds of men should be lulled and stagnate in matters of nature. They shall try and try again to better their condition by progress from a lesser to a higher degree of perfection. This is how the development works in the case of every single human being, and this was how every single generation developed from the beginning of the World". 50

This human desire to improve the social conditions has a startling resemblance to the social desire he introduced in the exposition of the catechism: More than twenty years earlier Pontoppidan had defined the orderly self-love as "a desire implanted in Man by God to make possible his true welfare and salvation". The book "Truth to Grod-fearingness" was founded upon a historical discourse: "We live in an era when secular wisdom and all types of knowledge founded upon this are on the path toward a higher degree than our ancestors could possibly have imagined" It indicates a consistence in the thoughts and ideas of Pontoppidan over the years and a conceptual consistence in his religious as well as in his secular texts.

The orderly and innocent self-love was an integrated concept in the moral philosophy of the 18th century that was fundamental to the construction of concepts of political economy: The orderly self-love was the invisible hand behind the development of economy and society. The conceptual history of self-love, as a social desire implanted by God, creates a new perspective in the cultural history of Denmark and Norway in the eighteenth century: A relationship is established between the discourse of the second Reformation and the discourse of social and economic improvement of society.

\section{Echoes of Pontoppidan: opposition and tradition in 19th century Denmark and Norway}

In December 1814, the revivalist preacher Hans Nielsen Hauge left prison in Christiania in Norway for the last time. The case against him had ended. Hauge had been convicted of violating the prohibition on religious gatherings (according to Konventikelplakaten from 1741) and of slandering pastors and authorities. That same year, Norway, following the Treaty of Kiel and after the Eidsvoll Constitution, was no longer tied to the central administration in Copenhagen,

\footnotetext{
${ }^{49}$ Henrik Horstbøll, "Cosmology and Economics", Scandinavian Economic History Review, vol. 2: (1989), p. 28.

50 Danmarks og Norges Oeconomiske Magazin, bd. 5, 1761, Fortale a2-4.
} 
which had controlled the process from afar. Immediately prior to the beginning of the long trial against Hauge, in 1804, he had visited the revivalist circles in Jutland, where the controversy between Pontoppidan and Bishop Balle was taking place. ${ }^{51}$

Hauge and the Hauge movement had a tremendous impact on the institutionalization of Pontoppidan's text in Norway in the 19th century. The resolution from 8th September 1818 states that Balle's text could continue to be used where it was already in use, while for the remainder public schools and confirmation instruction no other textbook could be used besides Pontoppidan's "Truth to God-fearingness" and Saxtorph's extracts of same. Balle's officially authorized textbook could be used, while Pontoppidan' had to be used for the future. The resolution was a provocation to the chancellery in Copenhagen and to the former administration.

To follow the history of the publication of Pontoppidan and to clarify the repercussions of the book in Norway through the 19th century would demand a detailed examination of the history of the Norwegian school and church. But in the mirror of the printed tradition of the text a general picture appears. ${ }^{52}$

From the year 1817 we find a continuous production of the complete Pontoppidan in the town Christianssand in the south of Norway. Saxtorph's abridged edition, the "Extracts of Erik Pontoppidan's Exposition excerpted for the Use by Simple Folk" is only preserved in a few copies before 1830. But new editions of the extracts are handed down from that year and repeatedly almost from every year throughout the century, and it was reprinted in all parts of Norway.

An official Commission published a new authorized extract of Pontoppidan in 1843. The members of the Commission, J. Kaurin, W. A Wexel and Chr. Keyser based their work on Saxtorph's extracts, but the new manual provoked a row. The reason was that according to the new textbook baptism alone entailed the rebirth of the person. The possibility of conversion after baptism was left out in the new extract and the same had happened to the possibility of rebirth by the Word of God for those who had fallen from the sacrament. ${ }^{53}$

The Saxtorph-extract was reissued continuously and it must have been the chief competitor to the edition of 1843. The authorities surrendered and in 1864 Harald Ulrik Sverdrup published a new extract of Pontoppidan that was authorized the following year. It was a return, or a retreat to the contents of the version of Saxtorph and thereby to the possibility of personal conversion and rebirth after the baptism. Sverdrup's extract survived other attempts to modernize Pontoppidan and at least 19 editions of his book were printed in the last decades of the 19 th century.

We have now returned to Hertzberg's little debate book from 1885, "The Shortcomings of Pontoppidan's Exposition and the Principles for a New One", with which I began this essay. Hertzberg argued that a modern education had to teach

${ }^{51}$ Elle Jensen, "De stærke Jyders første Tid", Kirkehistoriske Samlinger 6. R. 5: (1945) p. 21.

52 The survey of the editions is based on: Danske Afdelings systematiske katalog 3.2-416 ff. Det Kongelige Bibliotek, København, Brøndsted 1965: op.cit., pp. 64-65, Norsk Bog-Fortegnelse 18141847,1848 , Norsk Bog-Fortegnelse 1848-1865, 1870, Norsk Bog-Fortegnelse 1866-72, 1877, Norsk Bog-Fortegnelse 1883-1890, 1892.

53 E. Tønnesen: Nogle Bemerkninger til Forsuar for Pontoppidans Forklaring "Sandhed til Gudfrygtighed" $i$ Anledning af enkelte Forandringer, Udeladelser og Tillegg, 1847. 
Scripture and replace the exposition of the catechism with biblical history. The keywords of Pontoppidan were the chief target in his attack on the contents of the exposition. He disliked the way Pontoppidan worked with the Heart as a metaphor. In a modern discourse the heart connotates emotion: "Therefore it must be considered unfortunate that according to the manual enlightenment occupies the Heart and gives in reason a new light, in will a new longing, desire and strength". At the same time he asked the question: "Is selfishness, or 'self love' not always a $\sin$ ?"54 is like an echo of the words of Niels Tøxen in a completely different historical context.

Niels Hertzberg, an exponent of teacher college training for the institutionalised Norwegian schools, proved unable to cast Pontoppidan out of the market. The new textbooks, which the debate brought with it, were based primarily on Pontoppidan. Several new textbooks would subsequently appear, but Pontoppidan's would prove to outlive them. An abbreviated version by J. R. Sverdrup brought Pontoppidans book into the 20th century.

In Denmark, the original "Truth to God-fearingness" (1737 edition) appeared in Horsens in the 1840 s as part of a local victory over the authorities. It became permissible to teach children at home following Pontoppidan, as long as they were to be examined in school. New editions of the text were produced in Jutland, but it was only the unabridged text, which was republished. Saxtorph's "Extract" did not find renewed diffusion, as occurred in Norway. Pontoppidan's text was and remained the stuff of conflict in Denmark.

The authorities' acquiescence in the Pontoppidan case after four decades of resistance came too late to alter the peasants' position on the political chessboard. The "Peasant Circular" was the move from the authorities, which in November 1845 decided the game. The circular outlawed the holding of political meetings without the approval of the police, and it absolutely forbade meetings across parish boundaries. It was a political repetition of the religious konventikelplakat from the 18th century, and there was a narrow historical association between the revivalist movements and the new political movements in the countryside. When the "Peasant Circular" was again revoked in May 1846, the political association known as The Society of the Friends of the Peasant had become a reality.

That the legacy from the pietism of the 18th century allied itself with liberal political forces in the final phase of the absolutist regime is due to a combination of political events. The religious worldview and the key concepts, which we have investigated above, made their impact in different political contexts. Pietism and the religious movements did not have a specific political implication. This applied in the 18th century as well as in the 19th century. The Second Reformation could contribute to the modernization of the absolutist state's educational and administrative system from the $1730 \mathrm{~s}$, and the revivalist movements could contribute to the demise of the absolutist state institutions in the 1840s. The common denominator for the impact of pietism was individualization and responsibility. The internalisation of the Christian sense of belief individualized the relationship to God, and made salvation an individual matter. Responsibility and conscientious-

${ }^{54}$ N. Hertzberg: Manglerne ved Pontoppidans Forklaring og Principerne for en ny, 1885, p. 12-13. 


\section{Henrik Horstbøll}

ness followed enlightenment, "in reason a new light, in will a new longing, desire and strength".

The historical effects of Pontoppidan's religious instruction manual in Norway and Denmark differed only on the political surface. Underneath these controversies, the undercurrent was the same, whether the text was the expression of tradition after the Eidsvoll Constitution or the medium for opposition in the period before the Danish Constitution of June 1849. 